\title{
Spatial distribution and structure along ecological gradients: penaeid shrimps in a tropical estuarine habitat of Mexico
}

\author{
Roberto Pérez-Castañeda ${ }^{1,2}$, Omar Defeo ${ }^{1, *}$ \\ ${ }^{1}$ Laboratorio de Biología Pesquera, Centro de Investigación y de Estudios Avanzados, Unidad Mérida, AP 73 Cordemex, \\ 97310 Mérida, Yucatán, Mexico \\ ${ }^{2}$ Facultad de Medicina Veterinaria y Zootecnia, Universidad Autónoma de Tamaulipas, Carretera Victoria-Mante KM 5, \\ AP 263, Ciudad Victoria 87000, Tamaulipas, Mexico
}

\begin{abstract}
The spatial structure of salinity, submerged aquatic vegetation (SAV) and 4 shrimp (Farfantepenaeus spp.) populations along an estuarine habitat was evaluated seasonally, based on data gathered every $1 \mathrm{~km}$ along a 1-dimensional transect in Celestun Lagoon, Mexico. Geostatistical techniques were used to evaluate autocorrelation among data points along the transect, and to predict their spatial distribution by kriging. The estuarine habitat was characterized by persistent salinity gradients, decreasing from the seaward $(1 \mathrm{~km})$ to the inner $(18 \mathrm{~km})$ zone of the lagoon. SAV biomass was almost always spatially structured and best described by spherical variograms. Spatial partitioning between SAV species was evident: the seagrasses Halodule wrightii and Ruppia maritima dominated the seaward and central zones of the lagoon, respectively, whereas the green alga Chara fibrosa was constrained to the inner zone. Shrimp abundance also presented a marked spatial structure best described by spherical variograms. Spatial structure of shrimps, discriminated by species (F. aztecus, F. brasiliensis, F. duorarum and F. notialis) and population components (recruits, juveniles, subadults) was most evident in the Nortes season (i.e. the season of strong northerly winds) and poorly defined in the Dry season. Spatial partitioning among species and population components was not detectable. Total shrimps and recruits were generally most abundant close to the mouth of the lagoon, although juvenile and subadult abundance peaked farther from the mouth than recruits. Distance from the mouth was the most important factor determining the spatial distribution of shrimps along the estuarine habitat. At local scales, abundance and type of SAV beds were crucial factors determining the abundance and spatial distribution of shrimps. Analysis at different spatial scales allowed us to identify the importance of spatial structure in biotic and abiotic variables of this estuarine habitat.
\end{abstract}

KEY WORDS: Spatial structure $\cdot$ Penaeid shrimps $\cdot$ Farfantepenaeus $\cdot$ Estuarine habitat $\cdot$ Coastal lagoon

\section{INTRODUCTION}

The spatial distribution of species along ecological gradients responds to variations in biotic and abiotic factors. The development of regionalized variable theory and its recent application in ecology has allowed spatial analysis through geostatistical techniques
(Robertson 1987). Geostatistics nowadays constitutes one of the most powerful tools for describing and quantifying structures in spatial ecology (Robertson 1987, Rossi et al. 1992, Petitgas 1993). This approach explicitly takes into account the presence of spatial autocorrelation, i.e. the lack of spatial independence in ecological data, which has been viewed as a problem that can 
obscure the ability to understand spatial patterns in marine organisms. This is of utmost importance, because there is a huge amount of spatial dependence of biotic responses that has previously been ignored or erroneously addressed through the use of traditional statistics that assume independence between observations (Liebhold \& Gurevitch 2002). In marine populations, this approach has been undertaken for modeling spatial structure of populations (Pelletier \& Parma 1994, Maravelias et al. 1996), estimating biomass or abundance (Simard et al. 1992, Petitgas 1993, Maynou et al. 1998, Gutiérrez \& Defeo 2003), identifying cohorts in space (Roa \& Tapia 2000) and evaluating sampling designs (Defeo \& Rueda 2002), mainly in the open sea and in continental shelf waters. However, estuarine species (resident and transient) have received less attention concerning structure of ecological patterns and processes, with only some research recently documented on fish populations (Rueda 2001, Rueda \& Defeo 2001, 2003a,b).

Estuaries are very dynamic environments, where salinity affects habitat complexity and species distribution. Penaeid shrimps have a complex life cycle (Type 2 of Dall et al. 1990) that includes an estuarine phase, when postlarvae enter the mouths of estuaries, disperse into the inner reaches, settle and become juveniles, grow for several months, and subsequently migrate to the sea as subadults. In this context, salinity variations, together with submerged aquatic vegetation (SAV) beds, are key factors affecting their abundance and distribution (Minello \& Zimmerman 1991, Kenyon et al. 1997, Loneragan et al. 1998). Moreover, the biomass and taxonomic composition of SAV beds usually exhibit spatial and temporal variations as a function of salinity, which determines the availability and extent of these vegetated habitats (Adair et al. 1994, Lirman \& Cropper 2003).

Studies regarding the spatial distribution of penaeid shrimps in estuaries have categorized habitats according to salinity (e.g. seaward, middle, inner), substrata (vegetated and non-vegetated areas), SAV communities (seagrasses and algae), and energy of seagrass beds (high and low) (de Freitas 1986, Murphey \& Fonseca 1995, Loneragan et al. 1998, Howe et al. 1999, Pérez-Castañeda \& Defeo 2001). However, studies at finer spatial scales are rare and the simultaneous assessment of spatial structure of environmental variables and shrimp abundance along an estuarine habitat has not been undertaken.

Celestun Lagoon (Mexico) is a tropical estuarine habitat where 4 congeneric shrimp species co-occur (Pérez-Castañeda \& Defeo 2001): Farfantepenaeus aztecus, F. brasiliensis, F. duorarum and F. notialis. The lagoon has a strong spatial hydrological gradient with seasonal fluctuations, and thus analysis of the spatial structure of shrimp abundance and the surrounding environment over time could help to evaluate the importance of the estuarine habitat at a finer scale than has been done to date. The objectives of the present study were to: (1) determine and model the spatial structure of salinity, SAV biomass and shrimp abundance in Celestun Lagoon during different seasons; (2) evaluate spatial variations among shrimp species and population components along the estuarine habitat; and (3) assess the relative influence of environmental variables on shrimp populations.

\section{MATERIALS AND METHODS}

Sampling and laboratory procedures. This study was conducted in Celestun Lagoon (Mexico), a tropical estuarine habitat of ca. $21 \mathrm{~km}$ long, in the Gulf of Mexico (Fig. 1). It is a microtidal shallow lagoon with an almost flat bottom and a mean depth of $1.2 \mathrm{~m}$. The substratum is dominated by SAV beds, with inconspicuous bare areas. A narrow tidal channel is the major bathymetric characteristic, with a maximum depth of $3 \mathrm{~m}$ (Herrera-Silveira 1994, Herrera-Silveira et al. 1998). Shrimps are absent from the tidal channel because of bare substrata and high energy tidal currents. We con-

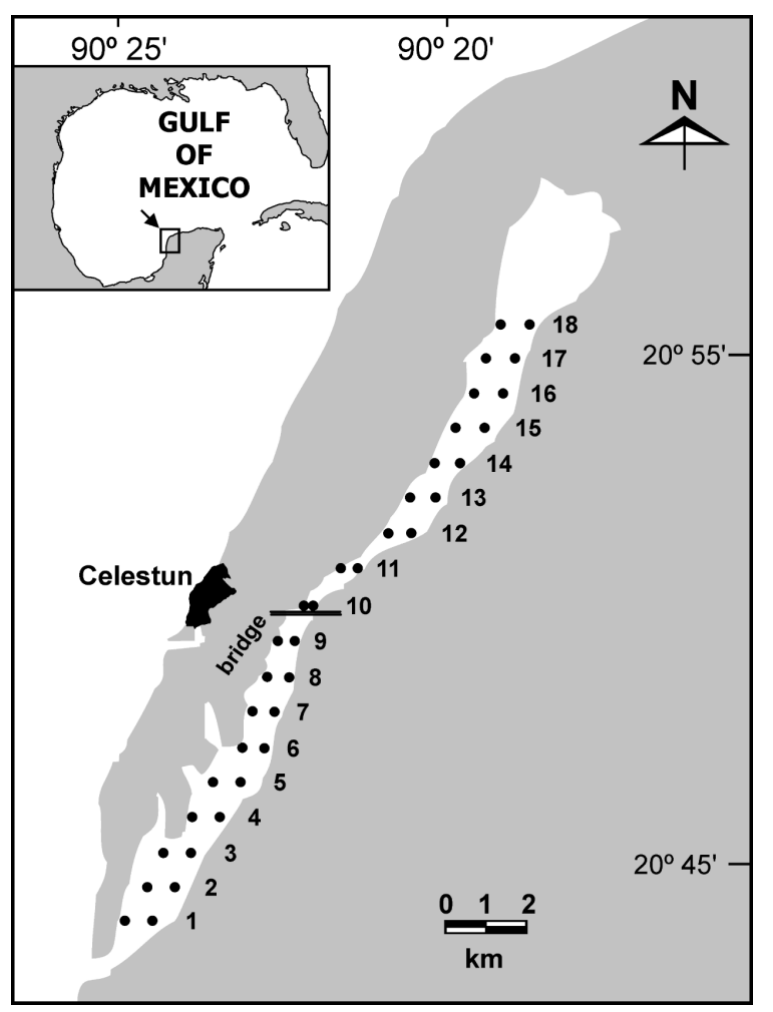

Fig. 1. Location of sampling sites $(\bullet)$ along estuarine habitat of Celestun Lagoon, Mexico. 1-18: distance $(\mathrm{km})$ from mouth 
ducted 3 seasonal sampling surveys during February, April, and September 2000, corresponding to the 'Nortes', 'Dry', and 'Rainy' seasons, respectively. We selected 18 pairs of sites situated at 1 to $1.5 \mathrm{~m}$ depth. Distance between consecutive pair of sites was $1 \mathrm{~km}$ (Fig. 1). In order to complete each survey during one morning, 3 teams sampled the lagoon simultaneously.

At each sampling site, shrimps were collected using a bottom net called a 'triangle', which was hand hauled $50 \mathrm{~m}$ by 1 person along the bottom parallel to the water's edge. This gear has a rigid and fixed opening mouth, and comprises 3 mangrove poles $(2.45 \mathrm{~m}$ wide, $1.25 \mathrm{~m}$ high) with attached net (1.5 m length, mesh size $1.3 \mathrm{~cm}$ ). All samplings were made under the same conditions (depth, time of day, trawl velocity) in order to minimize effects on catch efficiency associated with sampling conditions. It has been argued that SAV density and turbidity could also differentially affect catch efficiency of the trawling gear. Celestun Lagoon is characterized by high and constant turbidity because of continuous sediment resuspension and diffusion of 'tannins' from the mangroves throughout the lagoon. Consequently, a differential effect of turbidity on net efficiency is unlikely. Regarding SAV density, Loneragan et al. (1995) found little difference in trawl net efficiency for juvenile penaeids between seagrass beds that varied up to $300 \%$ in biomass (range 54 to $204 \mathrm{~g}$ $\mathrm{m}^{-2}$ ), a value very similar to those reported here (see 'Results'). Thus, we assume that catch efficiency was constant between sites and between seasons.

Samples were preserved in $70 \%$ ethyl alcohol. Each individual shrimp was measured (carapace length, CL) to the nearest $0.1 \mathrm{~mm}$ and separated by species, according to morphological characteristics, under a dissecting microscope (Pérez-Farfante 1970a,b). Specimens $<8.0 \mathrm{~mm}$ CL were identified only to genus level because of the lack of distinctive characteristics below this size. Shrimps were categorized into 3 population components: recruits, $\mathrm{CL}<8.0 \mathrm{~mm}$; juveniles, $\mathrm{CL} \geq 8.0$ and $<15.0 \mathrm{~mm}$; and subadults, $C L \geq 15.0 \mathrm{~mm}$.

At each site, salinity was measured for the first $10 \mathrm{~cm}$ of the water column. SAV collections comprised 3 replicate samples $\left(1 \mathrm{~m}^{2}\right.$ each) from 0,25 , and $50 \mathrm{~m}$ along a transect parallel to each $50 \mathrm{~m}$ trawl. SAV was bagged and placed on ice for later analyses. In the laboratory, the SAV was rinsed free of sediment, sorted to species level and oven-dried to constant weight at $70^{\circ} \mathrm{C}$ to determine biomass (dry weight, $\mathrm{g} \mathrm{m}^{-2}$ ). Roots, when present, were excluded from biomass estimations.

Analysis of spatial structure. Geostatistics: A geostatistical appraisal was performed to examine the spatial structure and distribution of salinity, SAV biomass (total and specific), and shrimp abundance (for each species and each population component) along the estuarine habitat. Geostatistics is a branch of applied statistics that focuses on the detection, modeling, and estimation of spatial patterns (Rossi et al. 1992) in spatially correlated data. Spatial autocorrelation occurs because samples collected close to each other are often more similar than samples collected farther apart. This particularly occurs when the variable sampled is spatially structured (e.g. in patches). In their simplest form, geostatistics involve 2 steps (Robertson 1987): (1) characterizing the spatial structure of the variable by means of a variogram, thus defining the degree of autocorrelation among the data points; (2) predicting values between measured points based on the estimated degree of autocorrelation. To this end, the variogram parameters are used for interpolating values, using a kriging algorithm that provides an error term for each value estimated, giving a measure of reliability for the interpolations.

In accordance with the main objective of this study, we explicitly utilized a 1-dimensional approach. To this end, we calculated the mean values of salinity, SAV biomass (total and specific), and shrimp abundance (for each species and each population component) for each pair of sampling sites allocated at $1 \mathrm{~km}$ intervals along the coastal lagoon. The 1-dimensional transects comprised 18 mean observations measured at a location $x$ defined with respect to its relative distance from the mouth of the Celestun Lagoon (1 to $18 \mathrm{~km}$ ).

Variogram fitting: The spatial autocorrelation of salinity, SAV biomass and shrimp abundance was evaluated by semivariance analysis through variograms, which quantify the spatial dependence of these variables. Changes in semivariance within a variogram represent the rate of deterioration of the influence of a given sample over increasingly remote zones in the study area (Matheron 1963). Because variograms tend to decompose at large lag intervals close to the maximum lag interval (Robertson 2000), the active lag distance we used in variographic analysis was close to $80 \%$ of the maximum lag. Uniform intervals ranging from 1 to $2 \mathrm{~km}$ were used, depending on the variable analyzed. A variogram $\gamma(h)$ was estimated for each 1-dimensional transect (comprising 18 mean values of the variable studied) using Matheron's (1965) estimator:

$$
\gamma(h)=\frac{\sum_{i=1}^{N_{h}}\left[Z\left(x_{i}+h\right)-Z\left(x_{i)}\right]^{2}\right.}{2 N(h)}
$$

where $Z\left(x_{i}\right)$ is the measured sample value at location $x_{i r}$ $Z\left(x_{i}+h\right)$ is another measured sample value separated from $x_{i}$ by a distance $h$ (measured in $\mathrm{km}$ ), and $N(h)$ is the number of pairs of observations separated by $h$. Several theoretical models (spherical, exponential, Gaussian, linear) were fitted to the experimental variograms, and the model that best explained the spatial structure was 
selected according to the coefficient of determination $\left(r^{2}\right)$ and the reduced sum-of-squares of the residuals (Cressie 1991). The models provide the following parameters: (1) the nugget-effect $\left(C_{0}\right)$, which reflects the spatial variability below the minimum lag distance that cannot be modeled with the current sampling resolution (i.e. $1 \mathrm{~km}$ in this case); (2) the sill $\left(C_{0}+C\right)$, which defines the asymptotic value of semivariance; and (3) the range $\left(A_{0}\right)$, defined as the distance over which autocorrelation is present. These parameters allow the proportion of sample variance explained by the spatially structured component $C /\left(C_{0}+C\right)$ to be estimated.

Interpolation: Once spatial dependence had been determined, we used variogram parameters to interpolate values on each transect for points not measured through punctual kriging (Matheron 1965). Punctual kriging provides an error term for each estimated value, thus giving a measure of reliability for the interpolations. Afterwards, kriging values were used to validate the fitted variogram through cross-validation. This procedure is based on a systematic removal of observations from the raw data set, one by one, which were then estimated by kriging. In this way, a graph was constructed of estimated $(E)$ versus observed $(O)$ values, which were fitted to a linear regression of the form $O=\alpha+\beta E$. Departures from a 1-to-1 line through the origin indicate model inadequacy. For this end, the simultaneous F-test (Dent \& Blackie 1979) was used to test the null hypothesis of slope $=1$ and intercept $=0$.
After modeling the spatial autocorrelation and validating the fitted variogram, a transect image of the analyzed variable, including observed data, interpolations and the variance of interpolations, was generated.

The interpolation was not carried out in cases where spatial autocorrelation was not detected, and only the observed data were plotted to depict any spatial trend. In the case of salinity, an ANCOVA was also performed with season as main factor, distance as covariate, and $\log$ (salinity) as dependent variable. This analysis was restricted to $\mathrm{Km} 2$ to 18 in order to fulfill ANCOVA requirements.

Relationship between shrimps and estuarine environment. Forward stepwise multiple regression analysis by season was used to assess the relative effect of salinity, SAV biomass (specific and total) and distance from the lagoon mouth on shrimp abundance. We focused on (1) recruits, because these affect subsequent shrimp abundance in Celestun Lagoon (PérezCastañeda \& Defeo 2003), and (2) total shrimps, to evaluate the response of all penaeid species combined. This analysis was undertaken using $F$ values of 1 and 0 , chosen a priori for variable entry and removal, respectively, until the best regression model was obtained. Partial correlations and redundancy of independent variables were also analyzed. When 2 significant variables were statistically redundant, we excluded the variable with the lower contribution to the model.

Table 1. Parameters and goodness-of-fit criteria used for variographic and cross-validation analyses of punctual kriging estimates for salinity and submerged aquatic vegation, SAV (species and total), in Celestun Lagoon. Mean values of each variable along a 1-dimensional transect were used. S: spherical; $C_{0}$ : nugget effect; $C_{0}+C$ : asymptotic semivariance; $A_{0}$ :distance (km) over which autocorrelation occurs; see 'Materials and methods' for details. Bias: simultaneous $F$-statistic for slope $=1$ and intercept $=0$; in all cases $\mathrm{p}>0.05$

\begin{tabular}{|c|c|c|c|c|c|c|c|c|c|c|}
\hline \multirow[t]{2}{*}{ Variable } & \multicolumn{6}{|c|}{ Theoretical variogram } & \multicolumn{4}{|c|}{ - Cross-validation } \\
\hline & Model & $C_{0} \quad C$ & $C_{0}+C$ & $A_{0}$ & $\%$ & $\mathrm{r}^{2}$ & a & $b$ & $\mathrm{r}^{2}$ & Bias \\
\hline \multicolumn{11}{|l|}{ Nortes } \\
\hline Salinity & none & - & - & - & - & - & - & - & - & - \\
\hline Halodule wrightii & $\mathrm{S}$ & 1 & 329 & 6.6 & 99.7 & 0.97 & -0.73 & 1.04 & 0.74 & $3.5 \times 10^{-3}$ \\
\hline Ruppia maritima & $\mathrm{S}$ & 10 & 3360 & 6.6 & 99.7 & 0.98 & -0.73 & 1.02 & 0.74 & $5.6 \times 10^{-5}$ \\
\hline Chara fibrosa & $\mathrm{S}$ & 10 & 3628 & 3.7 & 99.7 & 0.96 & 2.02 & 0.90 & 0.48 & $1.0 \times 10^{-4}$ \\
\hline Total SAV & $\mathrm{S}$ & 150 & 6509 & 9.9 & 97.7 & 0.99 & 2.13 & 0.96 & 0.68 & $1.0 \times 10^{-4}$ \\
\hline \multicolumn{11}{|l|}{ Dry } \\
\hline Salinity & none & - & - & - & - & - & - & - & - & - \\
\hline Halodule wrightii & $\mathrm{S}$ & 1 & 367 & 6.1 & 99.7 & 0.98 & -0.36 & 1.04 & 0.81 & $2.1 \times 10^{-3}$ \\
\hline Ruppia maritima & $\mathrm{S}$ & 6 & 417 & 7.2 & 98.6 & 0.98 & 1.40 & 0.83 & 0.46 & $5.8 \times 10^{-3}$ \\
\hline Chara fibrosa & $\mathrm{S}$ & $1 \times 10^{-2}$ & 220 & 6.0 & 100.0 & 0.99 & -0.27 & 1.27 & 0.80 & 0.74 \\
\hline Total SAV & none & - & - & - & - & - & - & - & - & - \\
\hline \multicolumn{11}{|l|}{ Rainy } \\
\hline Salinity & none & - & - & - & - & - & - & - & - & - \\
\hline Halodule wrightii & $\mathrm{S}$ & 1 & 583 & 8.5 & 99.8 & 0.98 & -0.37 & 1.00 & 0.75 & $9.5 \times 10^{-5}$ \\
\hline Ruppia maritima & $\mathrm{S}$ & 10 & 4578 & 5.9 & 99.8 & 0.98 & -1.27 & 1.02 & 0.72 & $4.9 \times 10^{-5}$ \\
\hline Chara fibrosa & $\mathrm{S}$ & 64 & 2609 & 5.8 & 97.5 & 0.98 & 0.57 & 0.94 & 0.67 & $1.1 \times 10^{-4}$ \\
\hline Total SAV & $\mathrm{S}$ & 10 & 4399 & 13.8 & 99.8 & 0.97 & 13.80 & 0.79 & 0.51 & $4.9 \times 10^{-3}$ \\
\hline
\end{tabular}


For each season and distance from the mouth of the lagoon, SAV was categorized into the major dominant species (Halodule wrightii, Ruppia maritima and Chara fibrosa: $98 \%$ of total SAV biomass), and the influence of each of these on shrimp abundance (ind. $\mathrm{m}^{-2}$ ) was evaluated through 3-way ANOVAs using SAV species, Season and Shrimp species or Population components as the main factors. When significant differences were detected, multiple comparisons were achieved using Tukey's test for unequal sample size (Zar 1999). The original values were log-transformed to fulfill ANOVA assumptions. Additionally, the relationship between SAV biomass and shrimp abundance (recruits and total) was evaluated through nonlinear fitting. To this end, we selected data from the Nortes season, because at this time shrimps were most abundant and exhibited a defined spatial structure.

\section{RESULTS}

\section{Spatial analysis}

Variographic analysis revealed that salinity was not spatially structured, resulting in a lack of fit to the theoretical variogram (Table 1 \& Fig. 2). Salinity exhibited a clear spatial gradient along the estuarine habitat, decreasing from the seaward $(1 \mathrm{~km})$ to the inner zone $(18 \mathrm{~km})$ of the lagoon. Salinity also showed seasonal variations ranging as follows: Nortes 9 to 36, Dry 19 to 35, Rainy 6 to 20 (Fig. 3). The spatial continuous salinity $(S)$ gradient followed a monotonically decreasing exponential function of distance $(D)$ from the mouth of the lagoon (Fig. 3) of the form:

$$
S=a e^{(-b D)}
$$

where $a$ and $b$ are significant parameters $(\mathrm{p}<0.01)$. (a)
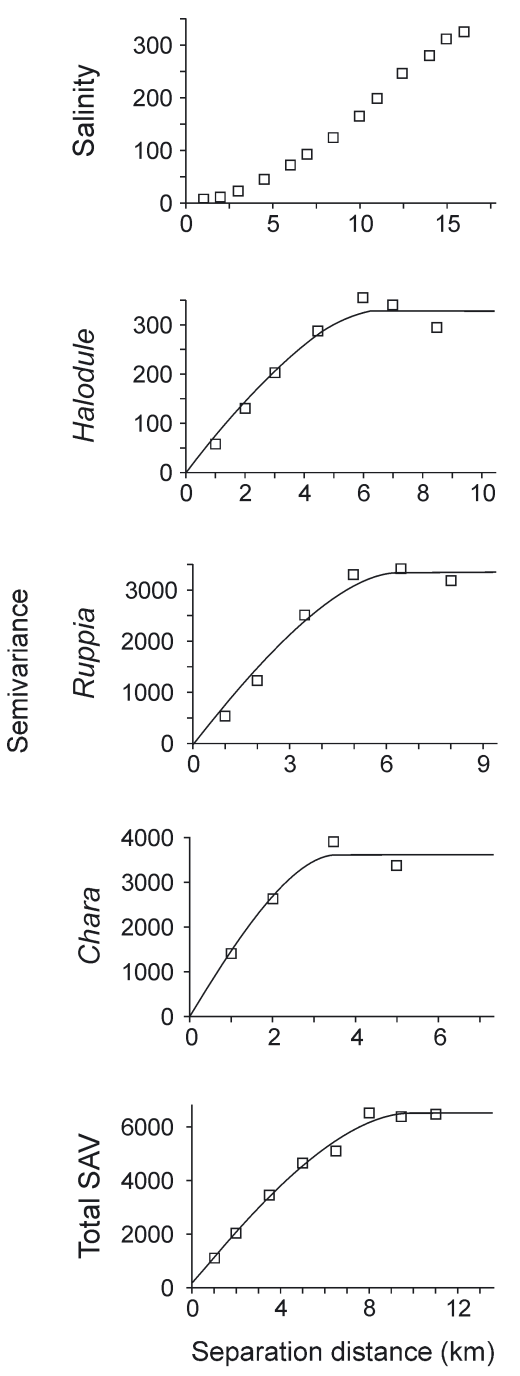

(b)
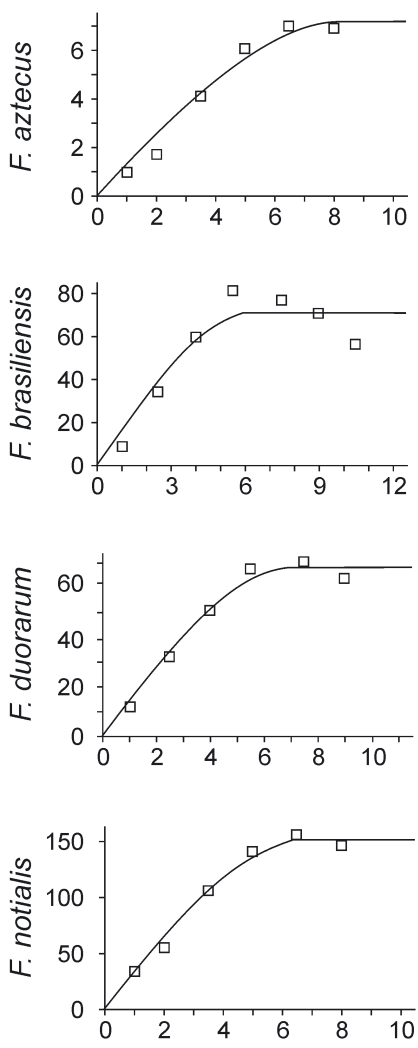

Separation distance $(\mathrm{km})$ (c)
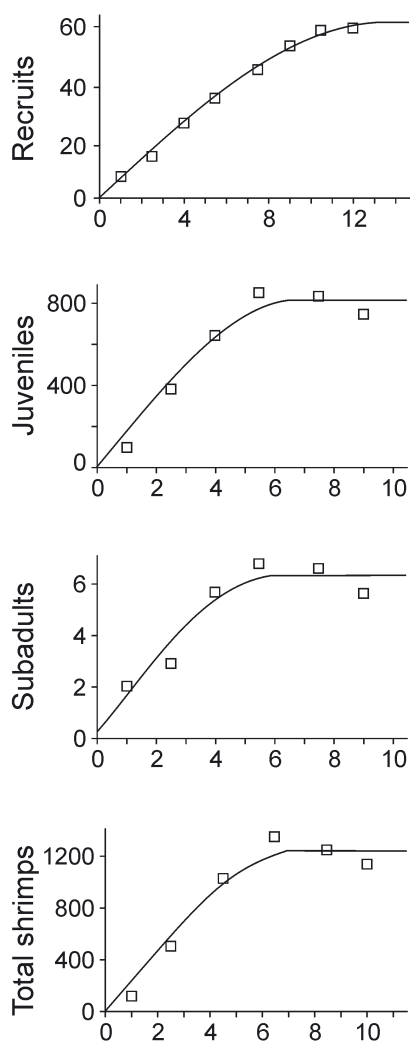

Separation distance $(\mathrm{km})$

Fig. 2. Theoretical variograms fitted in Nortes season for (a) biomass of submerged aquatic vegetation (SAV), and $(\mathrm{b}, \mathrm{c})$ shrimp Farfantepenaeus spp. abundance for (b) each species and (c) each population component. Spatial autocorrelation was not detected for salinity. Details of variogram models in Tables $1 \& 2$. Mean values of each variable along the 1-dimensional transect were used. Full specific SAV names are given in Table 1 


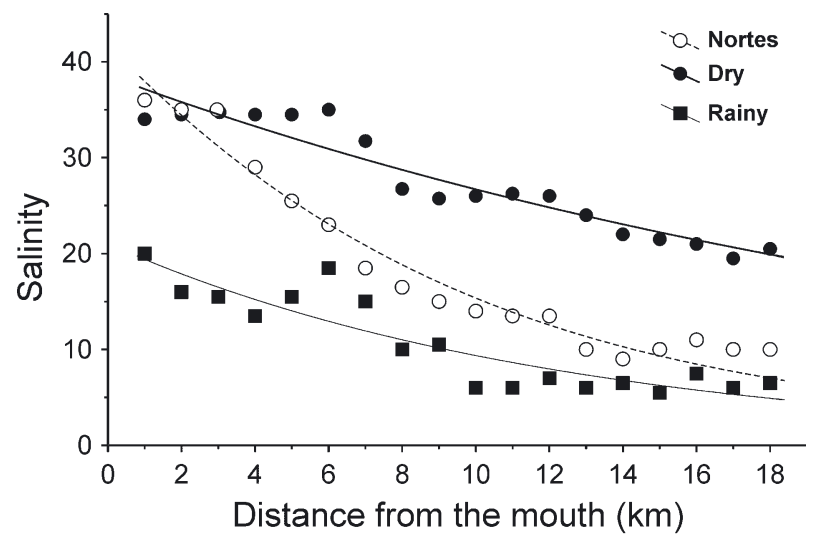

Fig. 3. Seasonal variations in salinity gradient along Celestun Lagoon. Data points correspond to mean salinity over 1 to $18 \mathrm{~km}$. Fitted exponential decay model is shown for each season
The model was valid for all 3 seasons. ANCOVA, performed with season as the main factor, distance (2 to $18 \mathrm{~km}$ ) as covariate and log (salinity) as dependent variable, showed that, for the same $D$, salinity was significantly higher in the Dry than in the Nortes and Rainy seasons (Tukey test, p < 0.01) (Fig. 3).

SAV biomass was always spatially structured, except for total SAV in the Dry season (Table 1). The spatial structure was best characterized by the spherical variogram defined as:

$$
\begin{array}{ll}
\gamma(h)=C_{0}+C\left[\frac{3}{2}\left(\frac{h}{A_{0}}\right)-\frac{1}{2}\left(\frac{h}{A_{0}}\right)^{3}\right] \text { for } h \leq A_{0} \\
\gamma(h)=C_{0}+C \quad \text { for } h>A_{0}
\end{array}
$$

with all parameters as defined previously.
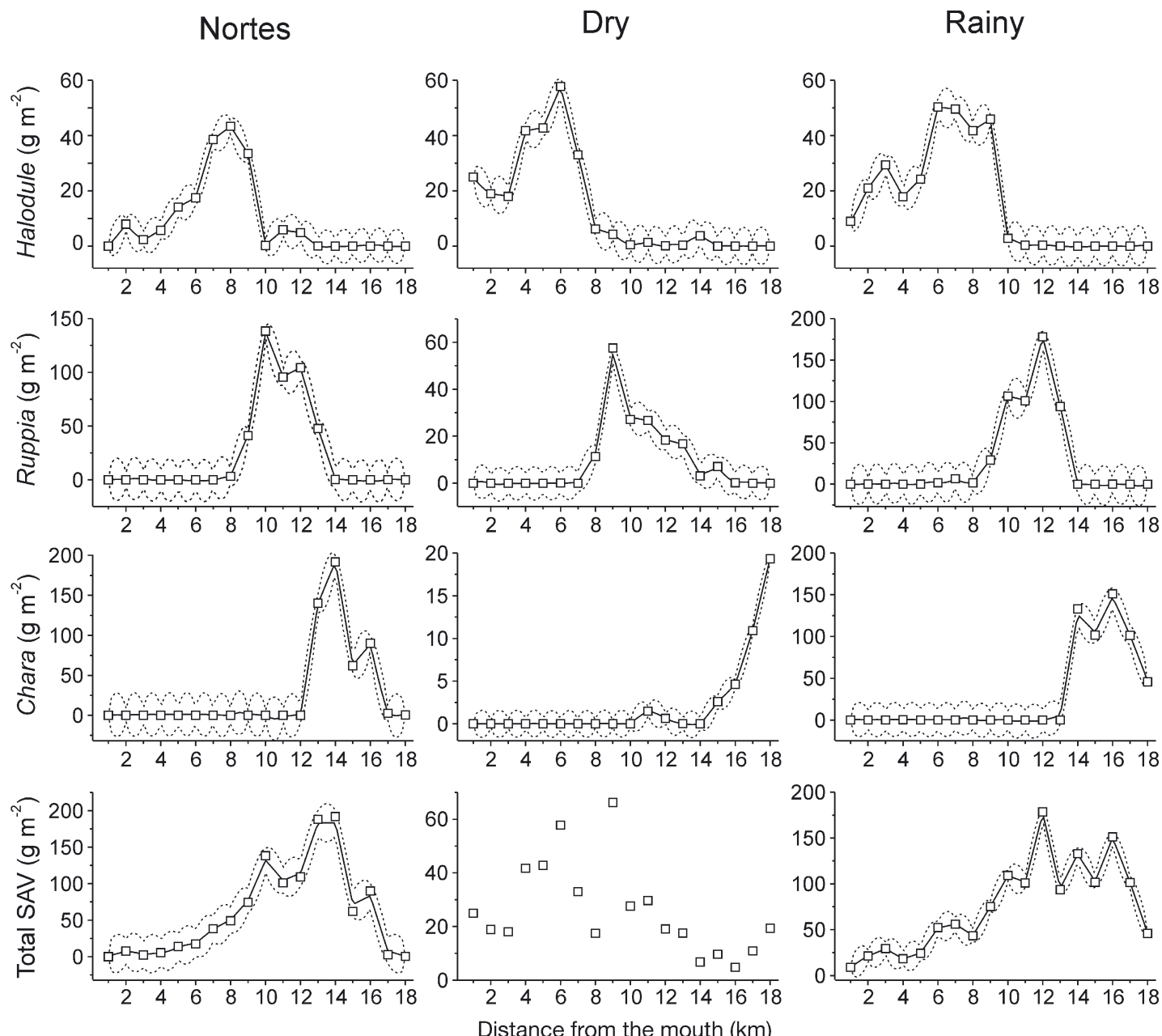

Fig. 4. Transect images for each season generated with punctual kriging, showing observed ( $\square$ ) and predicted mean (continuous lines) \pm SD (dotted lines) biomass for seagrasses Halodule wrightii and Ruppia maritima, green alga Chara fibrosa, and total SAV along estuarine habitat. Note different scales of $Y$-axes in Figs. 4, 5, 6 \& 7 
Variograms revealed a very high and stable spatial structure of SAV biomass: $C /\left(C_{0}+C\right) \geq 97.5 \%$. For the seagrass Halodule wrightii, the distance of spatial influence $A_{0}$ (interpreted as patch size) was 6.1 and $6.6 \mathrm{~km}$ in the Dry and Nortes seasons, respectively; however, it was largest $(8.5 \mathrm{~km})$ in the Rainy season (Table 1). The largest values of $A_{0}$ for the seagrass Ruppia maritima $(7.2 \mathrm{~km})$ and the alga Chara fibrosa $(6.1 \mathrm{~km})$ were in the Dry season, indicating seasonal variations in patch size of the different SAV species.

A clear spatial segregation of SAV species was consistently observed in all 3 seasons, with Halodule wrightii usually most abundant at distances $\leq 9 \mathrm{~km}$ from the mouth of the coastal lagoon, Ruppia maritima between 10 and $12 \mathrm{~km}$, and Chara fibrosa at $\geq 13 \mathrm{~km}$ (Fig. 4). SAV species experienced seasonal variations in overall biomass and spatial distribution along the coastal lagoon, especially C. fibrosa, whose biomass was much lower in the Dry season than in the other seasons. R. maritima exhibited ca. $50 \%$ lower biomass during the Dry season, whereas $H$. wrightii did not show important seasonal variations (Fig. 4).

Shrimp abundance presented a marked spatial structure, particularly during the Nortes and Rainy seasons, being best described by spherical variograms. The 4 Farfantepenaeus species were usually most abundant during Nortes, and major peaks were usually registered at distances $2-9 \mathrm{~km}$ from the lagoon mouth (Fig. 5). All species were spatially structured during Nortes (Table 2 \& Fig. 2), and F. aztecus and F. duorarum were spatially structured during the Rainy season also. Conversely, spatial structure was not evident during the Dry season, and thus variograms were not fitted for this period (Table 2). The proportion of the sample variance explained by the spatially structured component $C /\left(C_{0}+C\right)$ was always $\geq 98.3 \%$, and the distance of spatial influence $\mathrm{A}_{0}$ was in the range 3.0 to $8.4 \mathrm{~km}$ (Table 2).
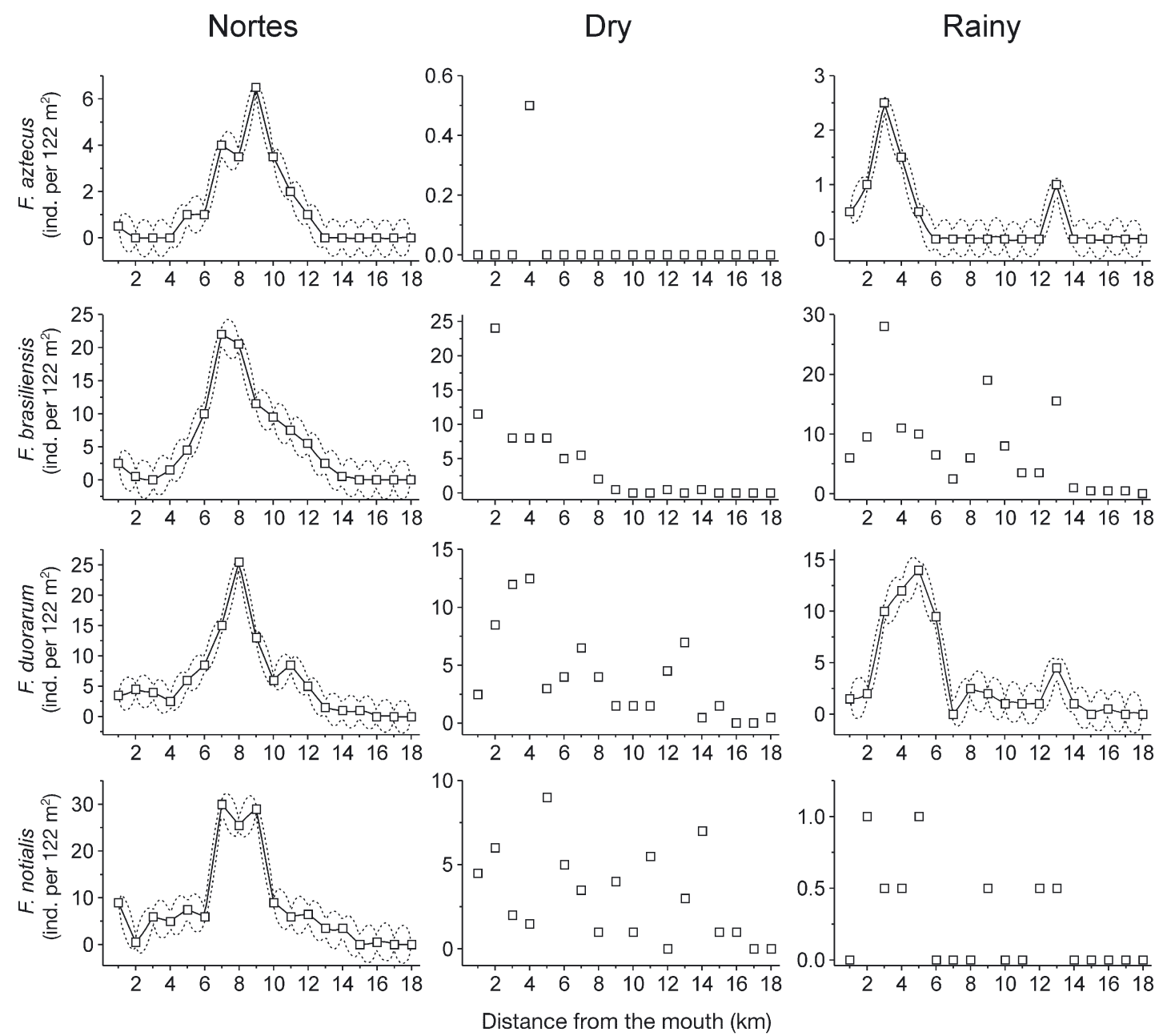

Fig. 5. Farfantepenaeus spp. Transect images for each season generated with punctual kriging, showing observed () and predicted mean (continuous lines) \pm SD (dotted lines) abundance of the 4 species along estuarine habitat 
Table 2. Farfantepenaeus spp. Parameters and goodness-of-fit criteria for variographic and cross-validation analyses of punctual kriging estimates for abundance (ind. per $122 \mathrm{~m}^{2}$ ) of shrimps along Celestun Lagoon for each species, each population component, and for total shrimps. ${ }^{*} \mathrm{p}<0.05$; further details as in Table 1

\begin{tabular}{|c|c|c|c|c|c|c|c|c|c|c|}
\hline \multirow[t]{2}{*}{ Variable } & \multicolumn{6}{|c|}{ - Theoretical variogram } & \multicolumn{4}{|c|}{-Cross-validation } \\
\hline & Model & $C_{0}$ & $C_{0}+C$ & $A_{0}$ & $\%$ & $\mathrm{r}^{2}$ & a & $b$ & $\mathrm{r}^{2}$ & Bias \\
\hline \multicolumn{11}{|l|}{ Nortes } \\
\hline F. aztecus & $\mathrm{S}$ & 0.01 & 7.2 & 8.4 & 99.9 & 0.98 & 0.08 & 0.93 & 0.69 & 0.24 \\
\hline F. brasiliensis & $\mathrm{S}$ & 0.10 & 71.0 & 6.3 & 99.9 & 0.90 & -0.58 & 1.10 & 0.90 & 0.39 \\
\hline F. duorarum & $\mathrm{S}$ & 0.10 & 68.2 & 7.0 & 98.3 & 0.99 & -0.24 & 1.03 & 0.73 & 0.01 \\
\hline F. notialis & $\mathrm{S}$ & 0.10 & 152.6 & 6.9 & 99.9 & 0.99 & 1.19 & 0.87 & 0.56 & 0.02 \\
\hline Recruits & $\mathrm{S}$ & 0.10 & 61.2 & 13.4 & 99.8 & 0.99 & 0.38 & 0.90 & 0.67 & 0.07 \\
\hline Juveniles & $\mathrm{S}$ & 1.00 & 812.5 & 6.7 & 99.9 & 0.97 & -1.65 & 1.09 & 0.87 & 0.02 \\
\hline Subadults & $\mathrm{S}$ & 0.24 & 6.3 & 6.1 & 96.2 & 0.91 & 0.73 & 0.69 & 0.33 & 1.79 \\
\hline Total shrimps & $\mathrm{S}$ & 1.00 & 1243.0 & 7.4 & 99.9 & 0.97 & -2.35 & 1.09 & 0.92 & 0.05 \\
\hline \multicolumn{11}{|l|}{ Dry } \\
\hline F. aztecus & none & - & - & - & - & - & - & - & - & - \\
\hline F. brasiliensis & none & - & - & - & - & - & - & - & - & - \\
\hline F. duorarum & none & - & - & - & - & - & - & - & - & - \\
\hline F. notialis & none & - & - & - & - & - & - & - & - & - \\
\hline Recruits & $\mathrm{S}$ & $1 \times 10^{-3}$ & 2.8 & 6.2 & 100 & 0.98 & -0.11 & 1.18 & 0.85 & $3.89^{*}$ \\
\hline Juveniles & none & - & - & - & - & - & - & - & - & - \\
\hline Subadults & $\mathrm{S}$ & 0.31 & 25.7 & 6.9 & 98.8 & 0.99 & -0.10 & 0.99 & 0.76 & $5.7 \times 10^{-4}$ \\
\hline Total shrimps & none & - & - & - & - & - & - & - & - & - \\
\hline \multicolumn{11}{|l|}{ Rainy } \\
\hline F. aztecus & $\mathrm{S}$ & $1 \times 10^{-3}$ & 0.4 & 3.0 & 99.8 & 0.92 & -0.03 & 1.08 & 0.59 & 1.06 \\
\hline F. brasiliensis & none & - & - & - & - & - & - & - & - & - \\
\hline F. duorarum & $\mathrm{S}$ & 0.01 & 19.9 & 3.7 & 99.9 & 0.95 & -0.40 & 1.10 & 0.73 & 0.15 \\
\hline F. notialis & none & - & - & - & - & - & - & - & - & - \\
\hline Recruits & $\mathrm{S}$ & 0.01 & 9.0 & 7.3 & 99.9 & 0.99 & -0.06 & 0.98 & 0.79 & $5.1 \times 10^{-3}$ \\
\hline Juveniles & S & 3.80 & 83.5 & 2.6 & 95.5 & 0.87 & -0.74 & 1.06 & 0.46 & $3.5 \times 10^{-3}$ \\
\hline Subadults & none & - & - & - & - & - & - & - & - & - \\
\hline Total shrimps & $\mathrm{S}$ & 0.10 & 158.3 & 2.4 & 99.9 & 0.87 & -0.88 & 1.04 & 0.41 & $1.1 \times 10^{-3}$ \\
\hline
\end{tabular}

All shrimp population components were spatially structured during the Nortes season, as revealed by spherical variograms. In the Rainy season, spatial structure in shrimp abundance was evident in all population components except subadults, whereas it was detectable only in recruits and subadults during the Dry season (Table 2 \& Fig. 2). The largest distance of spatial influence, $A_{0}$, was consistently found for recruits in the Rainy $(7.3 \mathrm{~km})$ and Nortes $(13.4 \mathrm{~km})$ seasons, usually ending at $\leq 6.7 \mathrm{~km}$ for juveniles and subadults. Total shrimp abundance registered $A_{0}$ values between 2.4 and $7.4 \mathrm{~km}$ (Table 2). Recruit abundance peaked between 1 and $6 \mathrm{~km}$ from the mouth of the coastal lagoon (Fig. 6). Juveniles were most abundant between 2 and 8 $\mathrm{km}$ from the mouth, showing a clear gradient from the seaward $(2 \mathrm{~km})$ to the inner zone $(18 \mathrm{~km})$ in the Dry season. Subadults peaked at $4 \mathrm{~km}$ from the mouth in the Dry season, and at $9 \mathrm{~km}$ in the Nortes and Rainy seasons (Fig. 6). Total shrimp abundance peaked at 3 $\mathrm{km}$ (Rainy) and $8 \mathrm{~km}$ (Nortes), remaining spatially structured along the estuarine habitat; however, it decreased with increasing distance from the mouth of the lagoon in the Dry season, indicating a gradient of abundance along the lagoon (Fig. 6).

\section{Relationship between environmental variables and shrimp abundance}

Seagrasses and distance from the mouth of the lagoon significantly explained the spatial variation in abundance of recruits and total shrimps during the Nortes season. Halodule wrightii influenced spatial variations in recruit abundance, whereas both species of seagrass were meaningful variables for total shrimps (Table 3). However, distance from the mouth was the only variable that significantly affected abundance of recruits and total shrimps in the remaining seasons. In all cases, shrimp abundance decreased with increasing distance from the mouth of the lagoon (Table 3).

Shrimp abundance (species and population components) differed significantly among the main factors (SAV species, Season, Species or Population component) and their interactions (ANOVAs, p < 0.05), except for the Population component $\times$ SAV species $\times$ Season interaction (Table 4). The significantly higher shrimp abundance during the Dry and Rainy seasons was usually observed in habitats dominated by Halodule wrightii, followed by those dominated by Ruppia 
Nortes
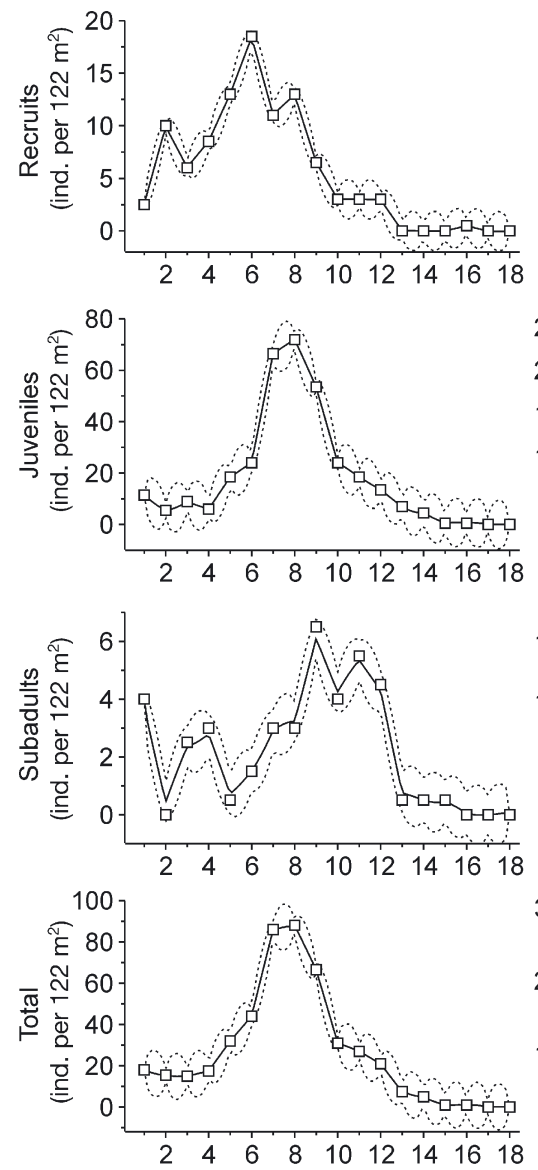

Dry
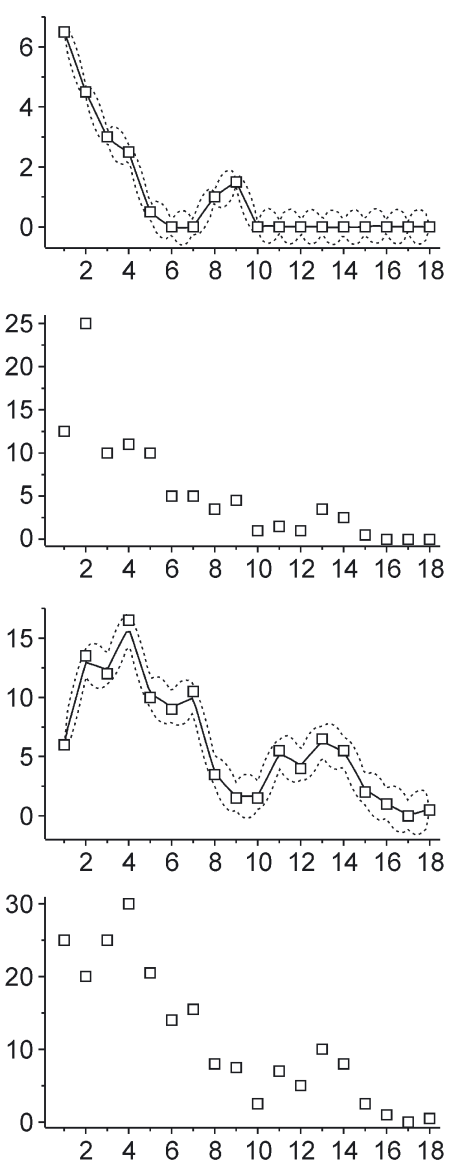

Distance from the mouth $(\mathrm{km})$
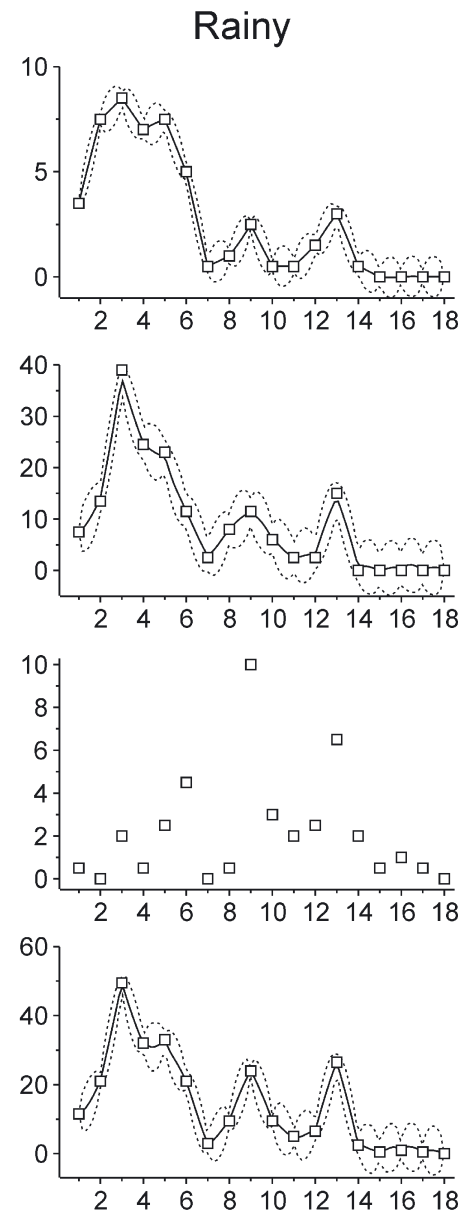

Fig. 6. Farfantepenaeus spp. Transect images for each season generated with punctual kriging, showing observed ( $\square$ ) and predicted mean (continuous lines) \pm SD (dotted lines) shrimp abundance (recruits, juveniles, subadults and total) along estuarine habitat

maritima. In the Nortes season, seagrass beds were also the most valuable habitat for shrimp, although their relative importance varied among species and population components. Recruits and total shrimps were always more abundant in $H$. wrightii beds, whereas all species and population components displayed the significantly lowest abundance in algal beds (Table 4 \& Fig. 7). An asymptotic relationship was fitted $\left(\mathrm{r}^{2}=0.77, \mathrm{p}<0.05\right)$ between biomass of $H$. wrightii and abundance of recruits, suggesting a seagrass threshold (ca. $20 \mathrm{~g} \mathrm{~m}^{-2}$ ) above which the number of recruits is not expected to increase (Fig. 8). The relationship between total SAV biomass and total
Table 3. Farfantepenaeus spp. Regression coefficients $( \pm \mathrm{SE})$ for predictor variables in forward stepwise multiple-regression analyses of shrimp abundance (recruits and total shrimps) for each season. Only variables significant in at least 1 season are shown. ns: variable removed (not significant); ${ }^{*} \mathrm{p}<0.05$; ${ }^{* *} \mathrm{p}<0.01 ;{ }^{* * *} \mathrm{p}<0.001$

\begin{tabular}{|lccc|}
\hline Variable & Nortes & Dry & Rainy \\
\hline Recruits & & & \\
Intercept & $8.48(1.96)^{* * *}$ & $3.20(0.67)^{* * *}$ & $6.99(0.95)^{* * *}$ \\
Halodule biomass $\left(\mathrm{g} \mathrm{m}^{-2}\right)$ & $0.21(0.06)^{* *}$ & $\mathrm{~ns}$ & $\mathrm{~ns}$ \\
Distance from mouth $(\mathrm{km})$ & $-0.53(0.16)^{* *}$ & $-0.23(0.06)^{* *}$ & $-0.45(0.09)^{* * *}$ \\
$\mathrm{R}^{2}$ adjusted & $0.64^{* * *}$ & $0.44^{* *}$ & $0.60^{* * *}$ \\
Total shrimps & & & \\
Intercept & $11.93(3.10)^{* *}$ & $24.95(2.11)^{* * *}$ & $31.18(5.40)^{* * *}$ \\
Halodule biomass $\left(\mathrm{g} \mathrm{m}^{-2}\right)$ & $1.85(0.09)^{* * *}$ & $\mathrm{~ns}$ & $\mathrm{~ns}$ \\
Ruppia biomass $\left(\mathrm{g} \mathrm{m}^{-2}\right)$ & $0.12(0.03)^{* *}$ & $\mathrm{~ns}$ & $\mathrm{~ns}$ \\
Distance from mouth $(\mathrm{km})$ & $-0.69(0.25)^{*}$ & $-1.49(0.19)^{* * *}$ & $-1.78(0.50)^{* *}$ \\
$\mathrm{R}^{2}$ adjusted & $0.96^{* * *}$ & $0.77 * * *$ & $0.41^{* *}$ \\
\hline
\end{tabular}




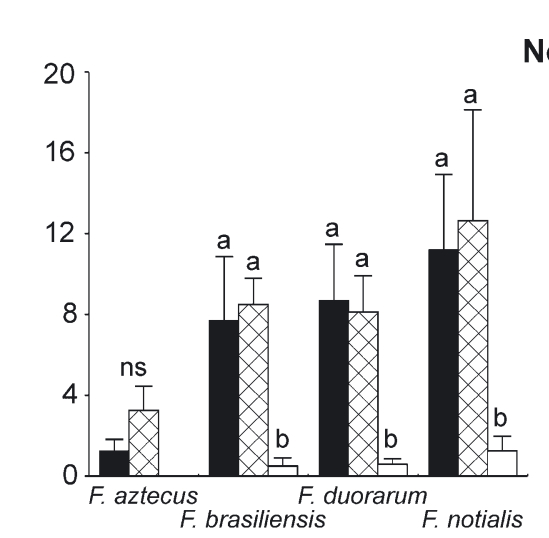

\section{Nortes}

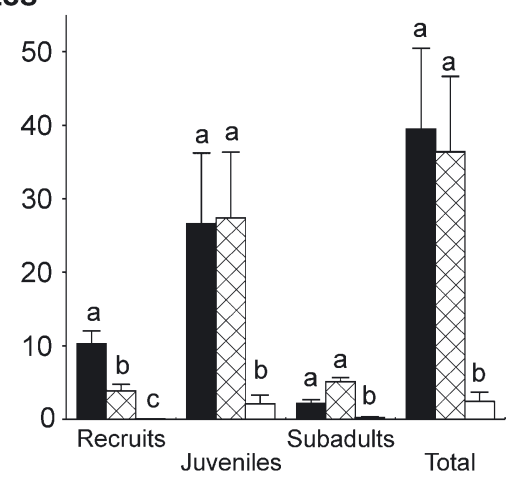

Dry

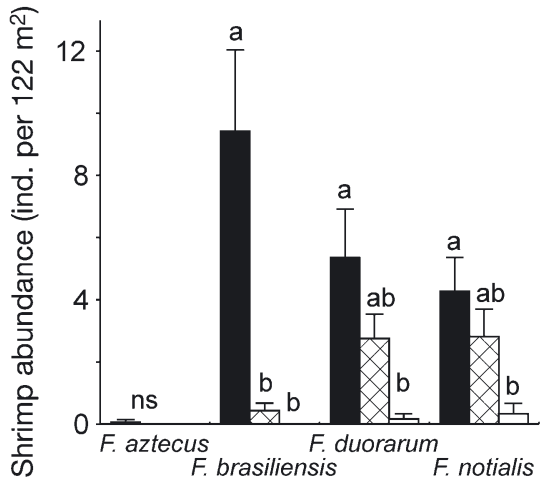

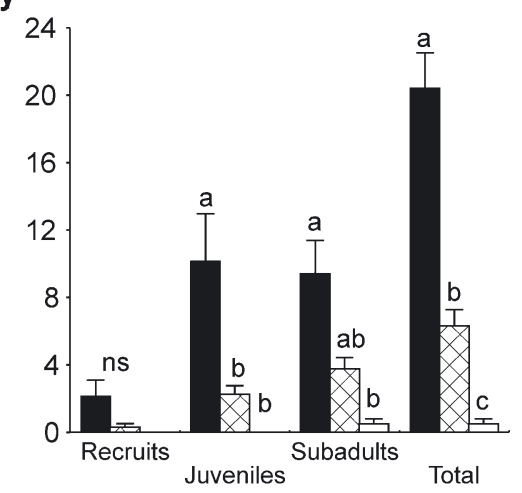

Rainy

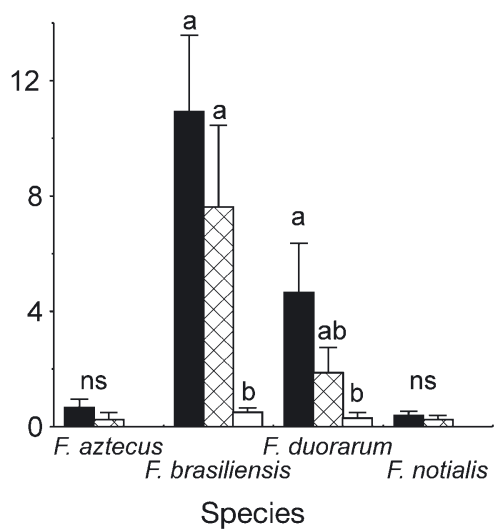

of the curve presenting the SAVshrimp relationship was mainly dominated by Halodule wrightii $(97 \%$ of total SAV in these cases), whereas the descending right-hand side was dominated by Ruppia maritima (92\% of total SAV) (Fig. 8).

\section{DISCUSSION}

\section{Environmental variables}

The spatial structure of the estuarine habitat was characterized by a persistent salinity gradient along Celestun Lagoon. Decreasing salinity with distance from the mouth has been documented in estuarine environments with similar geomorphologic characteristics to our study site (Blaber 1997). The biomass of the seagrasses Halodule wrightii and Ruppia maritima, the green alga Chara fibrosa and total SAV usually displayed a conspicuous spatial structure. Differences in patch size (approximated by $A_{0}$ ) among SAV species were noticeable: $A_{0}$ was consistently higher for seagrasses than for the alga $C$. fibrosa, reflecting a more restricted distribution of the algal beds. C. fibrosa almost disappeared in the Dry season at the highest salinities, resulting in an increase in the extent of the spatial distribution of $R$. maritima at the inner areas of the lagoon, as this species spread into the space vacated by the alga (see Fig. 4).

The main SAV species Halodule wrightii, Ruppia maritima and Chara fibrosa displayed a strong and persistent spatial segregation along the lagoon in all seasons. This segregation appears to be related to the horizontal salinity gradient, as in other estuarine habitats (Adair et al. 1994, HerreraSilveira et al. 1998, Lirman \& Cropper shrimp abundance $(\mathrm{N})$ was best fitted $\left(\mathrm{r}^{2}=0.75, \mathrm{p}<\right.$ 0.05 ) by a model of the form:

$$
\mathrm{N}=4.55 \mathrm{SAV} e^{(-0.0235 \mathrm{SAV})}
$$

This dome-shaped curve indicates a direct relationship between SAV biomass and shrimp abundance at biomass values $\leq 50 \mathrm{~g} \mathrm{~m}^{-2}$, after which shrimp abundance decreased (Fig. 8). The ascending left-hand side
2003). Seagrass beds were consistently located near the mouth of the lagoon, at the highest salinities. Algal beds were always located far from the mouth (13 to $18 \mathrm{~km}$ ), where salinity decreased to values down to 5 due to the influence of freshwater springs in the inner zone. The highest biomass fluctuation was observed in C. fibrosa, which has a lower tolerance to high salinities than seagrasses. Similarly, in a tropical Australian 
Table 4. Farfantepenaeus spp. Results of 3-way ANOVA of shrimp abundance for each species $(F$. aztecus, $F$. brasiliensis, $F$. duorarum and F. notialis) and each population component (recruits, juveniles, subadults and total shrimps). ${ }^{*} \mathrm{p}<0.05$;

$$
{ }^{* * *} \mathrm{p}<0.001
$$

\begin{tabular}{|lrrr|}
\hline Source of variation & df & MS & $F$ \\
\hline Species (1) & 3 & 1.65 & $25.98^{* * *}$ \\
SAV species (2) & 2 & 4.49 & $70.75^{* * *}$ \\
Season (3) & 2 & 1.57 & $24.70^{* * *}$ \\
$1 \times 2$ & 6 & 0.31 & $4.92^{* * *}$ \\
$1 \times 3$ & 6 & 0.47 & $7.44^{* * *}$ \\
$2 \times 3$ & 4 & 0.52 & $8.12^{* * *}$ \\
$1 \times 2 \times 3$ & 12 & 0.13 & $2.10^{*}$ \\
Error & 180 & 0.06 & \\
Population component (1) & 3 & 3.93 & $41.89^{* * *}$ \\
SAV species (2) & 2 & 16.33 & $174.21^{* * *}$ \\
Season (3) & 2 & 2.02 & $21.52^{* * *}$ \\
$1 \times 2$ & 6 & 0.65 & $6.91^{* * *}$ \\
$1 \times 3$ & 6 & 0.49 & $5.22^{* * *}$ \\
$2 \times 3$ & 4 & 0.50 & $5.31^{* * *}$ \\
$1 \times 2 \times 3$ & 12 & 0.14 & 1.47 \\
Error & 180 & 0.09 & \\
& & & \\
\hline
\end{tabular}

estuary, seagrass biomass did not change seasonally, but algal beds varied significantly (Haywood et al. 1995). Salinity has been identified as an overriding factor controlling algal growth in estuaries (Martins et al. 1999).

\section{Shrimp populations}

Shrimp abundance (species and population components) presented a marked spatial structure, mainly during the Nortes and Rainy seasons. Spatial partitioning among the 4 Farfantepenaeus was not detectable. Nevertheless, the abuncance of juveniles and subadults peaked somewhat farther from the lagoon mouth than that of recruits, suggesting the use of habitats in the inner areas as the shrimps grow (see Fig. 6). Distance from the mouth of the lagoon was the most important explanatory factor of variations in shrimp abundance along the lagoon. This factor was significant in all multiple regression analyses, whereas seagrass biomass was a significant predictor only in the Nortes season. Total shrimps and recruits were generally most abundant close to the lagoon mouth, decreasing between 1 and $18 \mathrm{~km}$ (Fig. 6). Howe et al. (1999) found significantly lower shrimp densities in oligohaline than in mesohaline areas, although distance from the mouth of the estuary was not explicitly evaluated in their study. Salinity and distance from the lagoon mouth are obviously closely related, and arguments as to which is the main controlling factor of shrimp distribution tend to be circular. Despite the redundancy of both variables in explaining shrimp abundance, distance from the lagoon mouth consistently explained higher variance than salinity. Even though it cannot be considered a purely structuring agent, it reflects the distance from the source of shrimp postlarvae throughout the estuarine system (see also Jenkins et al. 1998).

At local scales (i.e. patch size), abundance and type of SAV beds were crucial factors determining the spatial distribution and abundance of shrimps, as in other penaeid species (Haywood et al. 1995, Loneragan et al. 1998). Halodule wrightii and total SAV biomass were, respectively, adequate predictors of the abundance of recruits and total shrimps (Fig. 8). Among the SAV species, seagrass $H$. wrightii and Ruppia maritima beds contained significantly higher numbers of shrimps than alga Chara fibrosa beds. This could be due to the persistent spatial segregation of SAV species along Celestun Lagoon: postlarvae entering the lagoon settle on the first SAV bed they encounter (Bell \& Westoby 1986) which, in outer areas (i.e. 1 to $12 \mathrm{~km}$ ), tends to be dominated by the seagrasses $H$. wrightii and $R$. maritima. This fact, coupled with the continuous recruitment throughout the year (Pérez-Castañeda \& Defeo
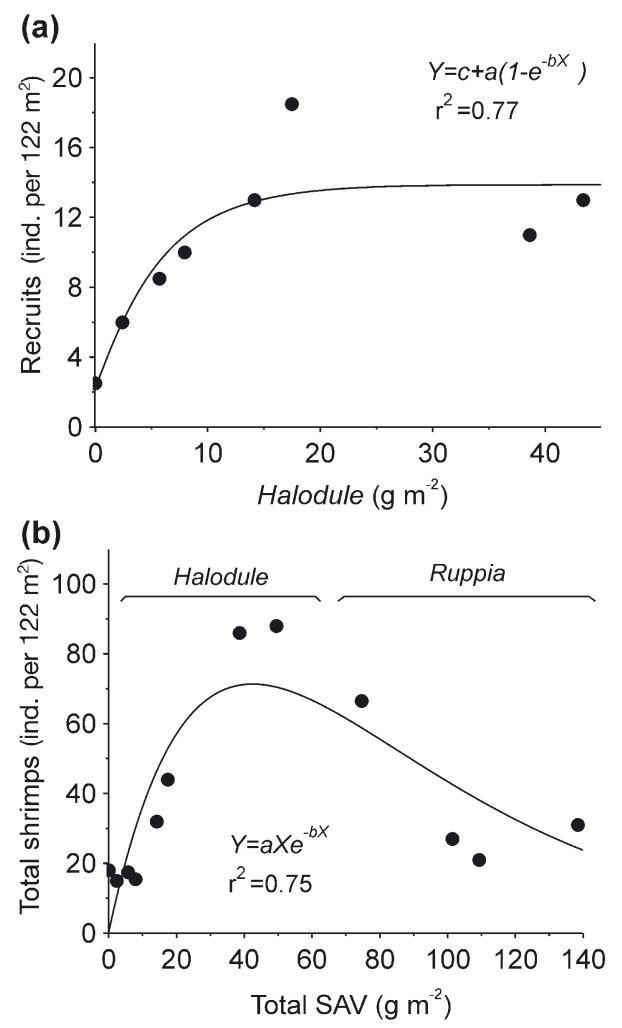

Fig. 8. Farfantepenaeus spp. Relationship between (a) biomass of Halodule wrightii and abundance of shrimp recruits, and (b) total SAV biomass and total shrimp abundance, indicating seagrass biomass ranges where $H$. wrightii and Ruppia maritima dominated SAV beds 
2001), could explain the consistently higher total shrimp abundance in outer beds of $H$. wrightii. As shown above, adequate assessment of the relevant scales of analysis is critical in this case, as associations between seagrass biomass and animal abundance may weaken when studies shift from local to larger spatial scales (Jackson et al. 2001).

In summary, this study represents the first effort to explicitly deal with the spatial structure of penaeid shrimps and environmental variables along an estuarine habitat gradient. Salinity was not spatially structured, and exhibited a clear spatial gradient. Conversely, SAV biomass and shrimp abundance showed different degrees of spatial structure. Although salinity can affect the availability of suitable habitats for shrimp, distance from the mouth of the lagoon and availability and biomass of seagrass beds were the most important factors influencing the spatial distribution of shrimp populations. The relative contribution of both variables depends on the spatial scale addressed. Finally, taking into account that larger shrimps used habitats farther from the lagoon mouth, we hypothesize that both pre- and post-settlement factors operate together to determine the spatial structure and distribution of shrimps along this lagoon.

Acknowledgements. This work is part of the $\mathrm{PhD}$ thesis of R.P.C. at CINVESTAV-IPN-Merida. Financial support from CONACYT (grant to R.P.C.) is acknowledged. Four referees provided useful suggestions that significantly improved the paper. We thank PRONATURA Península de Yucatán for field assistance and the Fishery Laboratory staff for help during field and laboratory activities.

\section{LITERATURE CITED}

Adair SE, Moore JL, Onuf CP (1994) Distribution and status of submerged vegetation in estuaries of the upper Texas coast. Wetlands 14:110-121

Bell JD, Westoby M (1986) Variation in seagrass height and density over a wide spatial scale: effects on fish and decapods. J Exp Mar Biol Ecol 104:275-295

Blaber JM (1997) Fish and fisheries of tropical estuaries. Chapman \& Hall, London

Cressie N (1991) Statistics for spatial data. John Wiley \& Sons, New York

Dall W, Hill BJ, Rothlisberg PC, Staples DJ (1990) The biology of the Penaeidae. In: Blaxter JHS, Southward AJ (eds) Advances in marine biology, Vol 27, Academic Press, London, p 1-489

Defeo O, Rueda M (2002) Spatial structure, sampling design and abundance estimates in sandy beach macroinfauna: some warnings and new perspectives. Mar Biol 140: 1215-1225

de Freitas AJ (1986) Selection of nursery areas by six southeast African Penaeidae. Estuar Coast Shelf Sci 23:901-908

Dent JB, Blackie MJ (1979) Systems simulation in agriculture. Applied Science, London

Gutiérrez N, Defeo O (2003) Development of a new scallop Zygochlamys patagonica fishery in Uruguay: latitudinal and bathymetric patterns in biomass and population structure. Fish Res 62:21-36

Haywood MDE, Vance DJ, Loneragan NR (1995) Seagrass and algal beds as nursery habitats for tiger prawns (Penaeus semisulcatus and P. esculentus) in a tropical Australian estuary. Mar Biol 122:213-223

Herrera-Silveira JA (1994) Spatial heterogeneity and seasonal patterns in a tropical coastal lagoon. J Coast Res 10:738-746

Herrera-Silveira JA, Ramírez J, Zaldivar A (1998) Overview and characterization of the hydrology and primary producer communities of selected coastal lagoons of Yucatán, México. Aquat Ecosyst Health Manag 1:353-372

Howe JC, Wallace RK, Rikard FS (1999) Habitat utilization by postlarval and juvenile penaeid shrimps in Mobile Bay, Alabama. Estuaries 22:971-979

Jackson EL, Rowden AA, Attrill MJ, Bossey SJ, Jones MB (2001) The importance of seagrass beds as a habitat for fishery species. Oceanogr Mar Biol Annu Rev 39:269-303

Jenkins GP, Keough MJ, Hamer PA (1998) The contributions of habitat structure and larval supply to broad-scale recruitment variability in a temperate zone, seagrassassociated fish. J Exp Mar Biol Ecol 226:259-278

Kenyon RA, Loneragan NR, Hughes JM, Staples DJ (1997) Habitat type influences the microhabitat preference of juvenile tiger prawns (Penaeus esculentus Haswell and Penaeus semisulcatus De Haan). Estuar Coast Shelf Sci 45: 393-403

Liebhold AM, Gurevitch J (2002) Integrating the statistical analysis of spatial data in ecology. Ecography 25:553-557

Lirman D, Cropper WP (2003) The influence of salinity on seagrass growth, survivorship, and distribution within Biscayne Bay, Florida: field, experimental, and modeling studies. Estuaries 26:131-141

Loneragan NR, Wang YG, Kenyon RA, Staples DJ, Vance DJ, Heales DS (1995) Estimating the efficiency of a small beam trawl for sampling tiger prawns Penaeus esculentus and P. semisulcatus in seagrass by removal experiments. Mar Ecol Prog Ser 118:139-148

Loneragan NR, Kenyon RA, Staples DJ, Poiner IR, Conacher CA (1998) The influence of seagrass type on the distribution and abundance of postlarval and juvenile tiger prawns (Penaeus esculentus and P. semisulcatus) in the western Gulf of Carpentaria, Australia. J Exp Mar Biol Ecol 228:175-195

Maravelias CD, Reid DG, Simmonds EJ, Haralabous J (1996) Spatial analysis and mapping of acoustic survey data in the presence of high local variability: geostatistical application to North Sea herring (Clupea harengus). Can J Fish Aquat Sci 53:1497-1505

Martins I, Oliveira JM, Flindt MR, Marques JC (1999) The effect of salinity on the growth rate of the macroalgae Enteromorpha intestinalis (Chlorophyta) in the Mondego estuary (west Portugal). Acta Oecol 20:259-265

Matheron G (1963) Principles of geostatistics. Econ Geol 58: 1226-1266

Matheron G (1965) La théorie des variables régionalisées et ses applications. Masson, Paris

Maynou FX, Sardá F, Conan GY (1998) Assessment of the spatial structure and biomass evaluation of Nephrops norvegicus (L.) populations in the northwestern Mediterranean by geostatistics. ICES J Mar Sci 55:102-120

Minello TJ, Zimmerman RJ (1991) The role of estuarine habitats in regulating growth and survival of juvenile penaeid shrimp. In: Deloach PF, Dougherty WJ, Davidson MA (eds) Frontiers of shrimp research. Elsevier, Amsterdam, p 1-16 Murphey PL, Fonseca MS (1995) Role of high and low energy 
seagrass beds as nursery areas for Penaeus duorarum in North Carolina. Mar Ecol Prog Ser 121:91-98

Pelletier D, Parma A (1994) Spatial distribution of Pacific halibut (Hippoglossus stenolepis): an application of geostatistics to longline survey data. Can J Fish Aquat Sci 51: $1506-1518$

Pérez-Castañeda R, Defeo O (2001) Population variability of four sympatric penaeid shrimps (Farfantepenaeus spp.) in a tropical coastal lagoon of Mexico. Estuar Coast Shelf Sci 52:631-641

Pérez-Castañeda R, Defeo O (2003) Influence of estuarine zonation on exploited shrimp populations in a Mexican biosphere reserve: a feature for management and conservation. J Mar Biol Assoc UK 83:781-784

Pérez-Farfante I (1970a) Diagnostic characters of juveniles of the shrimps Penaeus aztecus aztecus, P. duorarum duorarum, and P. brasiliensis (Crustacea, Decapoda, Penaeidae). US Fish Wildl Serv, Spec Sci Rep Fish 599

Pérez-Farfante I (1970b) Características diagnósticas de los juveniles de Penaeus aztecus subtilis, P. duorarum notialis y P. brasiliensis (Crustacea, Decapoda, Penaeidae). Mem Soc Cienc Nat 'La Salle' 30:159-182

Petitgas P (1993) Geostatistics for fish stock assessments: a review and an acoustic application. ICES J Mar Sci 50: 285-298

Roa R, Tapia F (2000) Cohorts in space: geostatistical mapping of the age structure of the squat lobster Pleuroncodes monodon population off central Chile. Mar Ecol Prog Ser

Editorial responsibility: Otto Kinne (Editor),

Oldendorf/Luhe, Germany
196:239-251

Robertson GP (1987) Geostatistics in ecology: interpolating with known variance. Ecology 68:744-748

Robertson GP (2000) GS+: geostatistics for the environmental sciences. Gamma Design Software, Plainwell, MI

Rossi R, Mulla DJ, Journel AG, Franz EH (1992) Geostatistical tools for modeling and interpreting ecological spatial dependence. Ecol Monogr 62:277-314

Rueda M (2001) Spatial distribution of fish species in a tropical estuarine lagoon: a geostatistical appraisal. Mar Ecol Prog Ser 222:217-226

Rueda M, Defeo O (2001) Survey abundance indices in a tropical estuarine lagoon and their management implications: a spatially-explicit approach. ICES J Mar Sci 58: 1219-1231

Rueda M, Defeo O (2003a) A bioeconomic multispecies analysis of an estuarine small-scale fishery: spatial structure of biovalue. ICES J Mar Sci 60:721-732

Rueda M, Defeo O (2003b) Linking fishery management and conservation in a tropical estuarine lagoon: biological and physical effects of an artisanal fishing gear. Estuar Coast Shelf Sci 56:935-942

Simard Y, Legendre P, Lavoie G, Marcotte D (1992) Mapping, estimating biomass, and optimizing sampling programs for spatially autocorrelated data: case study of the northern shrimp (Pandalus borealis). Can J Fish Aquat Sci 49:32-45

Zar JH (1999) Biostatistical analysis, 4th edn, Prentice-Hall, Upper Saddle River, NJ

Submitted: September 17, 2003; Accepted: February 10, 2004 Proofs received from author(s): May 26, 2004 